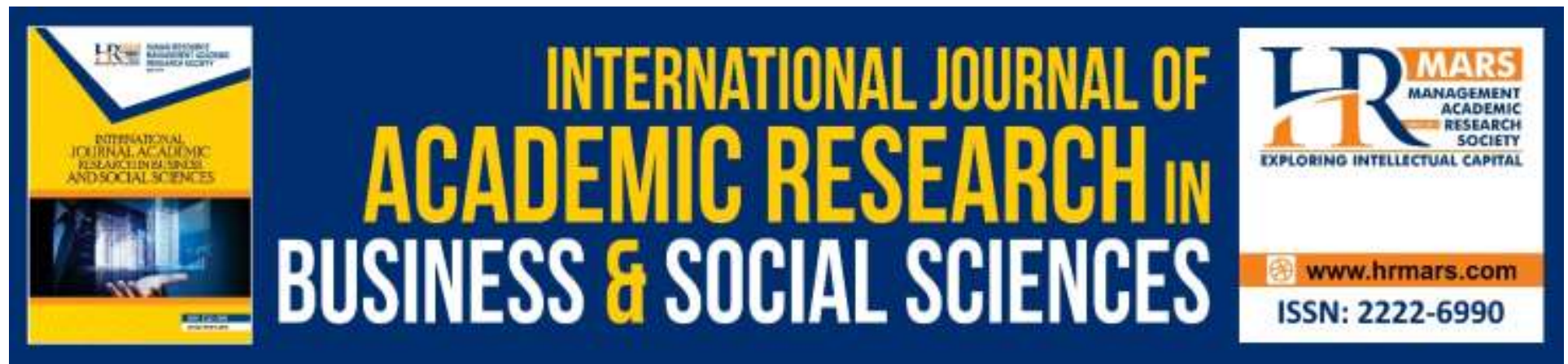

\title{
The Role of Valuer in Sustainable Valuation: A Review
}

\section{Lizawati Abdullah, Wan Nur Ayuni Wan Ab Rasid, Thuraiya Mohd}

To Link this Article: http://dx.doi.org/10.6007/IJARBSS/v8-i2/3981

DOI: 10.6007/IJARBSS/v8-i2/3981

Received: 28 Dec 2017, Revised: 25 Jan 2018, Accepted: 15 Feb 2018

Published Online: 18 Feb 2018

In-Text Citation: (Abdullah, Rasid, \& Mohd, 2018)

To Cite this Article: Abdullah, L., Rasid, W. N. A. W. A., \& Mohd, T. (2018). The Role of Valuer in Sustainable Valuation: A Review. International Journal of Academic Research in Business and Social Sciences, 8(2), 725734.

\section{Copyright: (C) 2018 The Author(s)}

Published by Human Resource Management Academic Research Society (www.hrmars.com)

This article is published under the Creative Commons Attribution (CC BY 4.0) license. Anyone may reproduce, distribute, translate and create derivative works of this article (for both commercial and non-commercial purposes), subject to full attribution to the original publication and authors. The full terms of this license may be seen at: http://creativecommons.org/licences/by/4.0/legalcode

Vol. 8, No. 2, February 2018, Pg. $725-734$ http://hrmars.com/index.php/pages/detail/IJARBSS JOURNAL HOMEPAGE

Full Terms \& Conditions of access and use can be found at http://hrmars.com/index.php/pages/detail/publication-ethics 


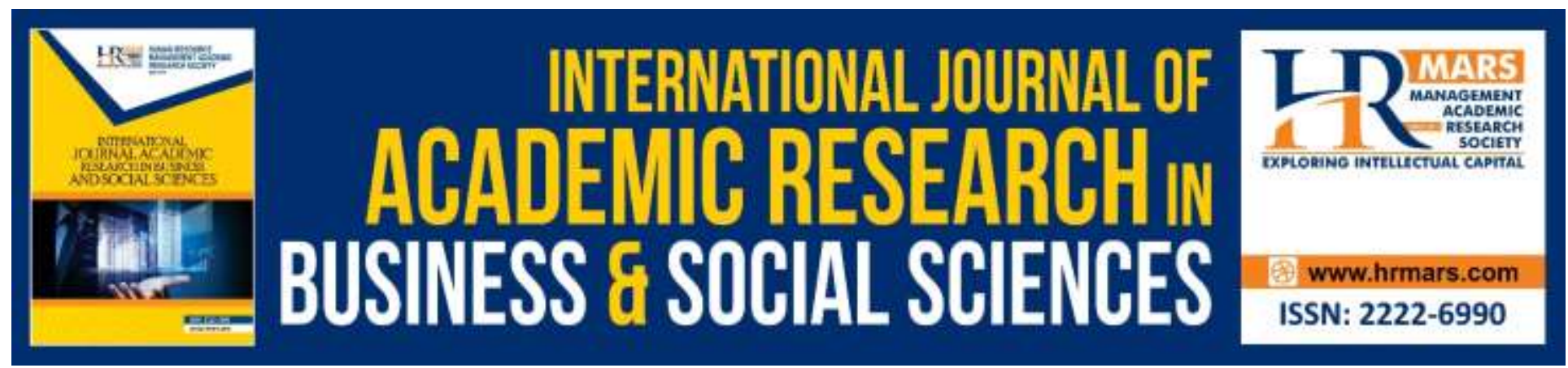

\title{
The Role of Valuer in Sustainable Valuation: A Review
}

\author{
Lizawati Abdullah, Wan Nur Ayuni Wan Ab Rasid, Thuraiya Mohd \\ Faculty of Architecture Planning and Surveying, Universiti Teknologi MARA, Perak Branch, Seri \\ Iskandar Campus, 32610 Seri Iskandar, Perak, Malaysia
}

\begin{abstract}
The purpose of this paper is to study the role of valuer in green building development. Green building is the main agenda of sustainability in built environment. While, valuer is one of the market player in built environment, which their existence indirectly influences the development of green building. Their capability in interpreting the value of building should be express clearly. Therefore, question arises whether valuer really understand green development concept and embrace the presence of green in valuation exercise. The objective of this study is to determine the issue in respect of valuer in valuing green building. Methodology used in this research is by conducting a review on previous research which valuer incorporating in green building valuation. This study discovers that there are issues and challenges in the role as valuer in green building valuation, lack of knowledge and awareness in green development as much as lack of information and data to interpret the value of green.
\end{abstract}

Keywords: Sustainability, Green Building, Valuer.

\section{Introduction}

The concept of sustainable was introduced way back in 1980s by the World Commission on Environment and Development. Sustainable development is defined as development that meets the present needs without compromising the future generation need (World Commission Environment and Development, 1987) which further explain through the three pillars of Triple Bottom Line Concept. The establishment of green rating tool in Malaysia i.e. Green Building Index (GBI) is to convey the objective of sustainable. To date, GBI has achieved success with more than 300 certified projects in the country since government make a move to promote a green building concept which began in 2009.

A large and growing body of literature on sustainable development issue as it is considering as multidisciplinary concept (Abbasian et. al, 2012). There are several ways of how people defines sustainable. In sustainable construction, the most viable solution is through green building development (Moran, 2013). Green building also known as sustainable building which being rated green by a green building rating system (RICS, 2005). These rating system, have set the 
assessment criteria on how the buildings can reduce the negative effect on the environment, worker productivity and public health.

The greenness of building being assess by the rating tools. The benefit of green building from the economic perspective have extensive amount being published. However, the value of green is often unclear. The main questions addressed here is what are the role of valuer in green building development. Is the existence of valuer is being recognize in green building development? The objectives of this paper are to determine the role of valuer in understanding the green building market and the issues challenged by valuer when incorporating green into the valuation process.

\section{Overview of Green Building Development}

Interest and the demand on sustainable property has grown rapidly in the last five years. It will increase in consistence with the rising number of global population in the future as a modern civilization seek and change for a better development (Ibrahim et al., 2013; Razali \& Adnan, 2015). The increasing of environmental or sustainable awareness not only influence the owner of the property but also shaken the stakeholders. This may lead organizations to focus more on improving their environmental performance management practices.

The determination created in 10th Malaysia Plan, Malaysia introduced GBI as green rating tool with the ultimate aim of saving 40\% of CO2 emission till 2020 and Malaysia can be main development to enter on viable environmental survival strategies (Ghazali, Raid, Kasim, \& Hussin, 2015; Jamaludin, Inangda, \& Ariffin, 2011). Nejat, Jomehzadeh, Taheri, Gohari, \& Abd. Majid, (2015) reported that buildings account for approximately $40 \%$ of global energy consumption and play an important role in the energy market. That huge percent of consumption lead to the negative impact on the environment.

The concept of green building is growing rapidly due to the increasing of public awareness in protecting the environment (Isa et. al, 2013). In built environment, green building is one of the methods for achieving sustainable objectives (Samari et.al, 2013). In addition, encouragement and incentives provided by the government, properties with green technology have bright opportunity in property market compared with non-green technology properties. The chances that the number of green building may perhaps rise in future.

\section{Role of Valuer}

Warren-myers (2012) highlighted that green building implementation is still new age and there is limited research in green residential. Green building in Malaysia are still an emerging concept and valuers are assigned the problematic task of navigating the effects of green on value (Nurick, Jeune, Dawber, Flowers, \& Wilkinson, 2015). Furthermore, the initial cost of design and construction are often given great attention by market players and little attention to energy and cost savings that apply to the entire life of the building. Many research such as Lorenz et.al, (2006), stated that through integrating green into property valuation theory and practice, it is belief that there will be a greater success in achieving a greener development. Ellison \& Sayce, (2007), support the statement that market players will continue struggle to success if the development and understanding of green features still low. 
In addition, valuers are unsure how to calculated for the green criteria in their valuation models as currently there is limited evidence on the financial performance of green buildings with the economic rationale for developing green buildings being based on almost entirely on person accounts evidence rather than facts or research (Jayantha \& Man, 2013; Nurick et al., 2015). Globally, this has meant that valuers are unable to clearly indicate whether green affect market value (Pitts \& Jackson, 2008), not necessarily because a correlation between the two does not exist, but rather because the ability of valuers to assess these features (Babawale \& A. Oyalowo, 2011), and identify the value of these features, is inherently difficult (Jayantha \& Man, 2013).

The valuer should have full or influence knowledge about green feature such as the type, size and location of the property will have a significant impact on value (RICS, 2011). This includes not only its general desirability from a design point of view, but also the cost and ease of adaptability to incorporate sustainable features, as this can vary significantly between different construction and design types (McCord, McCord, McClusky, Davis, \& Mcllhatton, 2014).

According to Lorenz, Trück, \& Lützkendorf, (2006), market players such as valuer is slowest in responding to the challenges imposed by green buildings. The reason valuer not interested with the implementation of green building is because the valuer not introduced to the green building function. Warren-Myers, (2012), stated that investors, occupiers, constructors and developers all blame each other for the lack of motivation to invest in green buildings based on the Cadman's 'vicious circle. To be relatively the role of valuers as advisors to the different stakeholders not perfectly played as figure 1.

Figure 1 : Breaking the Vicious Circle of Blame (Lorenz, 2008)

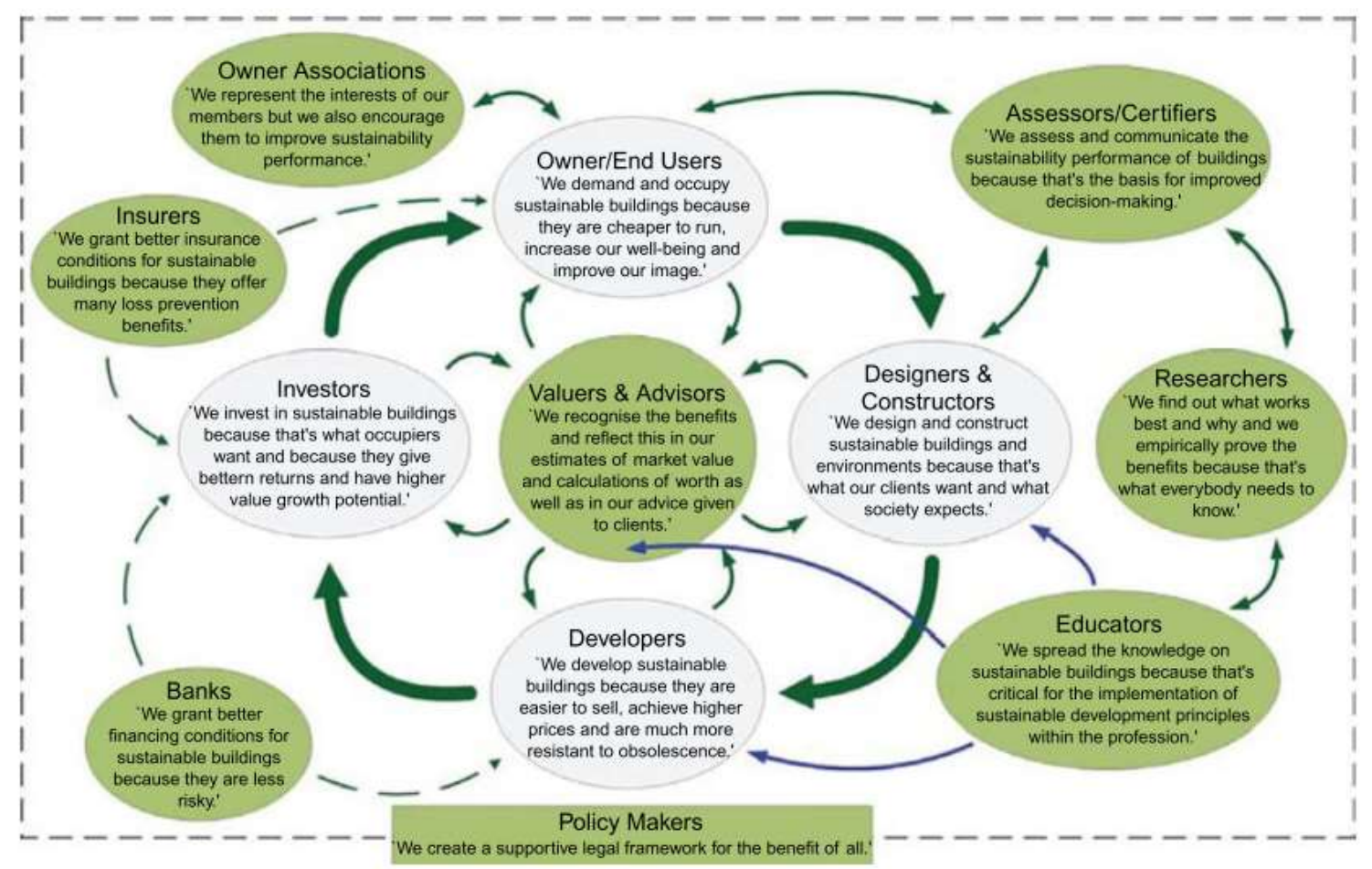

Warren-myers, (2013), states that the role of valuer in their profession as an valuer, not on market-leading or the creation of value for the market. It is about reflecting the market value for 
an asset at a certain time, given the dynamics of the market and related factors that can influence the response and actions of market stakeholders or market conditions

Further, Ellison \& Sayce, (2007), mentioned it is important for the valuer to engage in green building assessment of its market players go for green and the movement will effect when they do not understand how green rating work. The role of the valuer is to prepare a valuation report of the property. The approach adopted, and issues to consider, in preparation for the evaluation will depend, in part, to the destination, which in turn determines the value. The extent to which sustainability issues are specifically mentioned in the report will depend on the command whether they need to present the comprehensive calculation or otherwise.

Moreover, the valuer's role is to reflect market analysis. If the characteristics of sustainability analyzes as having an effect, this is to be consider into the calculation of the extent to which the buyer is informed and advised to consider such things. For example, to obtain the opinion of the Market Value, the assessment intended to reflect the market assessment of how these assets can be implemented in the future in terms of the ability to maintain rental income and benefit from the growth of the rent.

Valuers will need to develop knowledge of the implications it may advise building owners and residents, especially as the government introduced legislation aimed at reducing the impact of climate change and reduce carbon emissions. Indeed, it is the responsibility of valuers to be aware of this trend and find out how they feed through to rental values and capital. To identify and assess the sustainability of efficient, evaluators need to constantly strive to improve their knowledge of sustainability. So that they are aware of any new developments that may affect the value. This includes new technologies, law, public policy and financial measures, as well as the broader market attitude towards sustainability. The role of valuer as summarized in Table 1.

Table 1: Role of Valuer

\begin{tabular}{|l|l|l|}
\hline No & Role of valuer & Authors \\
\hline 1 & $\begin{array}{l}\text { Valuation report and analyzing } \\
\text { the market }\end{array}$ & $\begin{array}{l}\text { (Abidoye \& Chan, 2016; Lorenz \& Lützkendorf, 2011; } \\
\text { Lorenz et al., 2006; Warren Myers, 2013) }\end{array}$ \\
\hline 2 & $\begin{array}{l}\text { Identified and analyzing } \\
\text { sustainability features }\end{array}$ & $\begin{array}{l}\text { (Lorenz \& Lützkendorf, 2011; RICS, 2011; Sabu, Ahmad, } \\
\text { \& Abdullah, 2016) }\end{array}$ \\
\hline 3 & $\begin{array}{l}\text { Collecting data and } \\
\text { information serviced }\end{array}$ & (Lorenz \& Lützkendorf, 2008, 2011; RICS, 2011) \\
\hline 4 & $\begin{array}{l}\text { Knowledge of sustainability } \\
\text { 5 }\end{array}$ & $\begin{array}{l}\text { (Abidoye \& Chan, 2016; Asaju \& Ajayi, 2011; Lorenz \& } \\
\text { Lützkendorf, 2011; RICS, 2011; Sabu et al., 2016) }\end{array}$ \\
\hline
\end{tabular}

It is critical that valuers are fully mindful of the sustainability characteristics of residential buildings and the legislation, public policy and financial measures that may have an impact on property value. The property market will become progressively analyzing to sustainability considerations, over time. In advice, the valuer should alongside the trends and the changing views of stakeholders, and collect appropriate and sufficient sustainability data when valuing the property. All the data collected by valuer, to help them do a well-informed judgment on value 
and to provide clients with appropriate information on which to base their investment or purchase decisions.

\section{Methodology}

This research has focusing on role of valuer in valuing the green property. the methods that will be used to fulfill the highlighted objective in this research is based on secondary sources, which are a review and analysis data from of previous research. The secondary that refer to existing data which is available data from other researcher related to this topic. The reviewing on the data of secondary sources from published and unpublished that are journals, report, conference, thesis and articles.

\section{Discussion}

Green development in Malaysia is still at par behind and move at moderate level. Main problem faced by valuer in associated with valuing green building was the lack of transactional data and information (Warren-myers et. al, 2007), and the lack of knowledge (experience), Warren-myers, (2012). Since green buildings are still at emerging stage in Malaysia, if any robust transactional data that valuers can rely on for future valuations. Abdullah, Mohd, \& Sabu, (2016), stressed that, key role of the valuer is to determine the green value which can lead the direction of green building development.

Several previous literature explained and review about role of valuer in assessing the green property in real estate industry. Valuer not yet consider green or environmental performance in valuation exercise (Bullier et. al, 2011). Valuer's capability and sophistication to explain and justify his/her assumptions within the valuation report (Lorenz \& Lützkendorf, 2008).

Warren-myers, (2013) argues by the statement and stated that, valuers are acknowledging sustainability in their practice, they maybe inhibiting further investment in sustainability due to misleading assessments of sustainability in valuations. Others, review highlights on the issue of lack of evidence, and the applicability of current research into sustainability and value to the valuation profession in providing guidance and information in valuing real estate incorporating sustainability (Babawale \& Oyalowo, 2011)(Warren-Myers, 2012)(Jasimin \& Mohd Ali, 2015)(Sabu et. al, 2016). Lack of data makes it integrally difficult for valuers to assess value of sustainable buildings through current valuation approach and limit the modification into it (Warren Myers et al., 2007)(Huttler et.al, 2011). The issues relating to the valuer incorporating green into valuation are tabulated as in Table 2.

Table 2: Issue Incorporating Green into Valuation

\begin{tabular}{|l|l|l|l|l|}
\hline No & Author & Title & Method & Findings \\
\hline 1 & (Sabu et al., & Valuer's \\
Perspective On \\
The \\
Implementatio \\
\end{tabular}




\begin{tabular}{|c|c|c|c|c|}
\hline 2 & $\begin{array}{l}\text { (Jasimin \& } \\
\text { Mohd Ali, } \\
2015)\end{array}$ & $\begin{array}{l}\text { Valuation of } \\
\text { green office } \\
\text { building: A } \\
\text { preliminary } \\
\text { study of } \\
\text { Malaysian } \\
\text { insight } \\
\end{array}$ & $\begin{array}{l}\text { questionnair } \\
\text { e survey }\end{array}$ & $\begin{array}{l}\text { Klang Valley valuers recognize the } \\
\text { green features in valuation process, } \\
\text { but have limited information on } \\
\text { green building due to lack of datat. }\end{array}$ \\
\hline 3 & $\begin{array}{l}\text { (Elaine } \mathrm{Ng} \text {, } \\
\text { 2013) }\end{array}$ & $\begin{array}{l}\text { Impact of } \\
\text { green buildings } \\
\text { on the value of } \\
\text { property }\end{array}$ & $\begin{array}{l}\text { Questionnair } \\
\text { e survey }\end{array}$ & $\begin{array}{l}\text { Singapore valuers and industry } \\
\text { player need to increase awareness } \\
\text { and training to exchange the } \\
\text { knowledge to understand } \\
\text { sustainability and their economic and } \\
\text { environmental performance }\end{array}$ \\
\hline 4 & $\begin{array}{l}\text { (Warren } \\
\text { Myers, } \\
\text { 2013) }\end{array}$ & $\begin{array}{l}\text { Is the valuer } \\
\text { the barrier to } \\
\text { identifying the } \\
\text { value } \\
\text { of } \\
\text { sustainability? }\end{array}$ & Online survey & $\begin{array}{l}\text { Australian valuers are acknowledging } \\
\text { sustainability in their practice, but } \\
\text { maybe inaccurate or misjudged } \\
\text { assessments of sustainability in } \\
\text { valuations due to their limited } \\
\text { understanding of sustainability. }\end{array}$ \\
\hline 5 & $\begin{array}{l}\text { (Nurick et. } \\
\text { al, 2013) }\end{array}$ & $\begin{array}{l}\text { Incorporating } \\
\text { GBFIs into } \\
\text { commercial } \\
\text { property } \\
\text { valuation }\end{array}$ & $\begin{array}{l}\text { Interview and } \\
\text { online survey }\end{array}$ & $\begin{array}{l}\text { South African valuer recognize the } \\
\text { GBFIs incorporating in valuation but } \\
\text { they have limited knowledge and } \\
\text { experience. }\end{array}$ \\
\hline 6 & $\begin{array}{l}\text { (Pengfei, } \\
\text { 2011) }\end{array}$ & $\begin{array}{l}\text { How to } \\
\text { effectively } \\
\text { integrate } \\
\text { sustainability } \\
\text { into property } \\
\text { valuation }\end{array}$ & $\begin{array}{l}\text { Questionnair } \\
\text { e survey }\end{array}$ & $\begin{array}{l}\text { Swedish valuer have take into } \\
\text { account the green feature into } \\
\text { valuation process since } 2 \text { years ago. }\end{array}$ \\
\hline 7 & $\begin{array}{l}\text { (Warren- } \\
\text { Myers, } \\
\text { 2011) }\end{array}$ & $\begin{array}{l}\text { Sustainability - } \\
\text { the crucial } \\
\text { challenge for } \\
\text { the valuation } \\
\text { profession }\end{array}$ & $\begin{array}{l}\text { Questionnair } \\
\text { e survey }\end{array}$ & $\begin{array}{l}\text { Senior valuer have better knowledge } \\
\text { on sustainability compare to young } \\
\text { valuer, need to include curriculum on } \\
\text { sustainability - Australia and New } \\
\text { Zealand }\end{array}$ \\
\hline 8 & $\begin{array}{l}\text { (Babawale \& } \\
\text { Oyalowoi, } \\
\text { 2011) }\end{array}$ & $\begin{array}{l}\text { Incorporating } \\
\text { sustainability } \\
\text { into real estate } \\
\text { valuation: the } \\
\text { perception of } \\
\text { Nigerian } \\
\text { valuers }\end{array}$ & $\begin{array}{l}\text { Questionnair } \\
\text { e survey }\end{array}$ & $\begin{array}{l}\text { Nigeria valuers should enhance more } \\
\text { their knowledge on sustainability } \\
\text { because they are the principles driver } \\
\text { in sustainable development }\end{array}$ \\
\hline
\end{tabular}


INTERNATIONAL JOURNAL OF ACADEMIC RESEARCH IN BUSINESS AND SOCIAL SCIENCES

Vol. 8, No.2, February 2018, E-ISSN: 2222-6990 @ 2018 HRMARS

\begin{tabular}{|l|l|l|l|l|}
\hline 9 & $\begin{array}{l}\text { (Huttler et. } \\
\text { al, 2011) }\end{array}$ & $\begin{array}{l}\text { Integrating } \\
\text { energy } \\
\text { efficiency and } \\
\text { other } \\
\text { sustainability } \\
\text { aspects into } \\
\text { property } \\
\text { valuation } \\
\text { methodologies } \\
\text { barriers, } \\
\text { impacts }\end{array}$ & $\begin{array}{l}\text { Questionnair } \\
\text { e survey } \\
\text { Immovalue } \\
\text { study - case }\end{array}$ & $\begin{array}{l}\text { Limited market data, but 93\% agree } \\
\text { to green will generate higher market } \\
\text { value -survey among valuers from } \\
\text { various country }\end{array}$ \\
\hline 10 & $\begin{array}{l}\text { (Northeast- } \\
\text { midwest } \\
\text { Institute } \\
\text { and Delta } \\
\text { Institute, } \\
\text { 2008) }\end{array}$ & $\begin{array}{l}\text { Removing } \\
\text { market } \\
\text { barriers } \\
\text { green } \\
\text { development }\end{array}$ & A workshop & $\begin{array}{l}\text { Knowledge gaps and communication } \\
\text { shortfall - the consumer do not know } \\
\text { the benefit of green building because } \\
\text { the expertise i.e appraiser do not } \\
\text { have knowledge - Chicago appraiser }\end{array}$ \\
\hline
\end{tabular}

\section{Conclusion and Recommendations}

This research has explained the central importance of valuer in green building valuation. The valuer responsible to the real estate industry to ensure that a valuation reflects the element of green. The role of valuers is to have knowledge and aware on sustainability. It helps the market to recognize the impact of green and the economic benefit that can be gain by the owner of green building.

As an emerging market, issue on lack of data or market sale is one of the challenges to the valuer. Further, lack of knowledge and awareness on green building can be enhance by educating through training or workshop. Government or regulator bodies should play their role, by providing training, guideline or a platform to promote sustainability.

\section{Acknowledgement}

The authors thank Universiti Teknologi MARA Cawangan Perak, our employers for providing all necessary support in ensuring conclusion of this research. We also acknowledge and wish to extend heartfelt gratitude to the FRGS under the Higher Education Ministry for funding this research and our submission to the journals.

\section{Corresponding Author}

Lizawati Abdullah, Department of Estate Management, Faculty of Architecture, Planning and Surveying, UiTM Perak Campus Seri Iskandar, 32610 Perak, Malaysia

Email: lizaw327@perak.uitm.edu.my

\section{References}

Abdullah, L., Mohd, T., \& Sabu, R. (2016). A Conceptual Framework of Green Certification Impact on Property Price. In MATEC Web of Conferences (Vol. 66).

Abbasian,E., Nazari, M., \& Nasrindoost, M. (2012). Sustainable development strategies for energy 
INTERNATIONAL JOURNAL OF ACADEMIC RESEARCH IN BUSINESS AND SOCIAL SCIENCES

Vol. 8, No.2, February 2018, E-ISSN: 2222-6990 @ 2018 HRMARS

sector in Iran. International Jurnal of Academic Research in Business and Social Sciences, 2(9), 216-229

Abidoye, R. B., \& Chan, A. P. C. (2016). Critical determinants of residential property value: professionals' perspective. Journal of Facilities Management, 14(3), 283-300.

Asaju, A. S., \& Ajayi, M. A. (2011). Bridging the Gap Between Land Resource Exploitation and Sustainable Development in Nigeria.

Babawale, G. K., \& Oyalowo, A. B. (2011). Incorporating Sustainability into Real Estate Valuation: the Perception of Nigerian Valuers. Journal of Sustainable Development, 4(4), 236-248.

Ellison, L., \& Sayce, S. (2007). Assessing sustainability in the existing commercial property stock: Establishing sustainability criteria relevant for the commercial property investment sector. Property Management, 25(3), 287-304.

Georgia Warren-Myers. (2012). The value of sustainability in real estate: a review from a valuation perspective. Journal of Property Investment \& Finance, 30(2), 115-144.

Ghazali, M. M., Raid, M. M., Kasim, A. C., \& Hussin, K. (2015). Impact of Indoor Environmental Quality ( IEQ ) and Innovation ( IN ) Features on Residential Property Price in Malaysia : A Review. In ERES 2015 (pp. 63-73).

Ibrahim, F. A., Wira, M., Shafiei, M., Said, I., \& Ismail, R. (2013). Malaysian Housing Developers' Readiness in Green Homes Development, 28(3), 343-352.

Jamaludin, A., Inangda, N., \& Ariffin, A. (2011). Energy performance: A comparison of four different multi-residential building designs and forms in the equatorial region. Clean Energy and.

Jayantha, W. M., \& Man, W. S. (2013). Effect of green labelling on residential property price : a case study in Hong Kong. Journal of Facilities Management, 11(1), 31-51.

Lorenz, D., \& Lützkendorf, T. (2008). Sustainability in property valuation: theory and practice. Journal of Property Investment \& Finance (Vol. 26).

Lorenz, D., \& Lützkendorf, T. (2011). Sustainability and property valuation. Journal of Property Investment \& Finance, 29(6), 644-676.

Lorenz, D., Trück, S., Lützkendorf, T., \& Lorenz, D. (2006). Addressing risk and uncertainty in property valuations : a viewpoint from Germany.

Moran, K. (2010). The effect of sustainability on property value. Thesis. Rinker School of Building Contruction

McCord, J., McCord, M., McClusky, W., Davis, P. T., \& Mcllhatton, D. (2014). Effect of public green space on residential property values in Belfast metropolitan area. Journal of Financial Management of Property and Construction, 19(2), 117-137.

Nejat, P., Jomehzadeh, F., Taheri, M. M., Gohari, M., \& Abd. Majid, M. Z. (2015). A global review of energy consumption, $\mathrm{CO} 2$ emissions and policy in the residential sector (with an overview of the top ten $\mathrm{CO} 2$ emitting countries). Renewable and Sustainable Energy Reviews, 43, 843862.

Nurick, S., Jeune, K., Le Dawber, E., Flowers, R., \& Wilkinson, J. (2015). Incorporating GBFIs into Commercial Property Valuation. Journal of Sustainable Real Estate, 7(1), 21-40.

Pitts, J., \& Jackson, T. O. (2008). Green Buildings: Valuation Issues and Perspectives. The Appraisal Journal, 76(2), 115.

Razali, M. N., \& Adnan, M. Y. (2015). Sustainable property development by Malaysian property companies. Property Management, 33(5), 451-477. 
Report of the World Commission on Environment and Development: Our common future (1987)

RICS. (2011). Sustainability and residential property valuation Sustainability and residential property.

Sabu, R., Ahmad, H., \& Abdullah, L. (2016). Valuer's Perspective on the Implementation of Green Building Development (p. 9). International Real Estate Research and Symposium (IRERS), 2016

Samari, M., Godrati, N., Esmaeilifar, R., Olfat, P., \& Shafiei, M. W. (2013).The investigation of the barriers in developing green building in Malaysia. Modern Applied Science 7(2).

Warren-Myers, G. (2012). The value of sustainability in real estate: a review from a valuation perspective. Journal of Property Investment \& Finance (Vol. 30).

Myers, W. G. (2013). Is the valuer the barrier to identifying the value of sustainability? Journal of Property Investment \& Finance, 31(4), 345-359.

Myers, W. G., Reed, R., \& Robinson, J. (2007). The Relationship between Sustainability and the Value of Office Buildings. 13th Annual Pacific Rim Real Estate Conference, (January), 1-22. 